\title{
Full- and part-time wage differences in Spain: An analysis along the wage distribution ${ }^{1}$
}

\author{
Hipolito Simon, (IEI-IEB, University of Alicante, Alicante, Spain) \\ Esteban Sanroma, (Department of Economics, University of Barcelona, Barcelona, Spain) \\ Raul Ramos, (AQR-IREA, University of Barcelona, Barcelona, Spain)
}

\begin{abstract}
:
Purpose: The purpose of this paper is to examine wage differences between part- and full-time workers distinguishing by gender by using a large Spanish matched employer-employee data set and an econometric decomposition that permits to decompose wage differences by quantiles of the wage distribution.

Design/methodology/approach: The research is based on cross-section matched employer-employee microdata from a large representative survey (the Encuesta de Estructura Salarial) which is carried out with a harmonised methodology common to all European Union member countries and that has been designed specifically to provide reliable evidence about characteristics of the wage distribution such us wage differentials associated with the type of working time. From a methodological point of view, the econometric decomposition technique proposed recently by Fortin et al. (2011) to decompose wage differences between part-time and full-time workers by quantiles of the wage distribution is applied. This methodology has the advantage over similar techniques that provides a detailed decomposition of wage differentials and has not been used before to examine the wage impact of part-time jobs.
\end{abstract}

Findings: The results show that the significant raw wage gap that part-time workers experience in Spain differs substantially along the wage distribution. In the case of part-time females, the wage disadvantage is mostly explained by their relative endowments of characteristics (and particularly by their lower endowments of human capital and their segregation into low-wage sectors) but a significant wage penalty still persists, increasing along the wage distribution. In the case of males the wage disadvantage is only found in the lower part of the distribution and it is due both to their worst endowments of characteristics and a significant wage penalty.

Research limitations/implications: The evidence for Spain shows that the part-time work tends to affect differently to the wages of males and females, with a higher part-time penalty for males, as predicted by the "flexibility stigma" hypothesis, and penalising low-qualified men in the lower part of the wage distribution and highqualified women in the upper part of the distribution the most.

Originality/value: The analysis contributes to the literature by examining wage differences along the wage distribution for both genders using econometric decomposition methods, an aspect that to the authors' knowledge has been examined only scarcely in the international literature with non-conclusive evidence and has not been examined in previous studies for the Spanish case. In this vein, Spain is a particularly interesting analysis case from an international perspective of the wage consequences of part-time jobs, given that in contrast with most other advanced countries a majority of part-time employment in this country is involuntary and this phenomenon is especially affecting disadvantaged groups.

Keywords: Earnings, Part-time workers, Pay differentials, Wage distribution

\footnotetext{
${ }^{1}$ This work was supported by the Spanish Ministry of Economy and Competitiveness under Grants ECO201341022-R, ECO2013-41310-R, 2014 SGR-420 and CSO2014-55780-C3-2-P (National R\&D\&I Plan).
} 


\section{Introduction}

Recently, many governments have considered part-time jobs as a response to economic crisis and subsequent unemployment rise, given that they offer greater flexibility to firms regarding the use of their labour force while at the same time facilitating job creation. However, part-time jobs are usually associated to lower wages, high temporality (with lower firing costs), and fewer worker rights, like paid holidays or remuneration for medical leave. There is a wide literature confirming this view. In particular, part-time employees earn less in terms of hourly wages than full-time employees and this wage gap is not explained by differences in the characteristics between both groups of workers in term of personal characteristics (Hirsch, 2005, among others). Moreover, part-time workers usually have reduced access to social security benefits (Houseman and Matchiko, 1998), fewer labour progress opportunities (Tilly, 1990; Russo and Hassik, 2008), smaller pensions (Gimm and Arber, 1998; O'Connell and Gash, 2003), less labour stability (Muñoz Bustillo et. al., 2008; Fernández-Kranz et. al., 2014) and a lower unionisation rate (Belous, 1988).

In Spain, part-time employment has increased significantly in last decades (from $4.2 \%$ in 1987 to $15.6 \%$ in 2015). The current value is still below the European Union and the Euro Area averages $(19.6 \%$ and $21.6 \%$, respectively), mainly due to the fact that Spanish firms have traditionally achieved flexibility in the use of their workforce mainly through fixed-term contracts (the fixed-term employment rate is of $25.2 \%$ in 2015). Spain's increasing trend of part-time employment will probably continue in the future due to legal changes approved recently allowing more flexibility in the number of working hours. Taking into account moreover that on the contrary to most other advanced countries a majority of part-time employment in Spain is involuntary (more than 63\% in 2015, with $72 \%$ for men and $60 \%$ for women) and that Spain has currently the highest rate of youth involuntarily working part-time in all the advanced countries (the rate of youth 15-24 years working involuntarily in part-time jobs is $22 \%$ in Spain compared with the OECD average of a 4\%: OECD, 2015), there is a clear interest to analyse the wage consequences of part-time jobs in this country.

Previous studies for the Spanish economy have focused on differences in average wages and have obtained quite different results regarding the wage penalty of part-time workers when compared to full-time ones depending on the dataset employed. For instance, Cebrián et al. (2000) using 1994 European Community Household Panel (ECHP) household data obtained a positive wage premium of 12 $\log$ points for female part-time workers and of $30 \log$ points for those working less than 15 hours per week controlling just for individual characteristics. In a later work, using 1995 ECHP data but including additionally job controls like sector and occupation, these authors did not obtain evidence of the existence of a wage penalty for part-time female workers (Cebrián et al., 2001). Pissarides et al. (2005) and Pagan (2007) using more recent waves of the ECHP also arrived to the conclusion that there is a positive wage premium for part-time workers in Spain both for males and females. Yet, 
these results contrast with those of O'Dorchai et al. (2007) who using matched employer-employee microdata from the 1995 wave of the Structure of Earnings Survey observed a wage penalty for Spanish part-time males. Finally, Fernández-Kranz and Rodríguez-Planas (2011) and Fernández-Kranz et al. (2014) using administrative register data from the Continuous Sample of Working Histories also estimated significant wage penalties for Spanish middle-aged females.

In this article, we analyse wage penalisation for part-time workers in the Spanish labour market, distinguishing among men and women. The database used in the empirical analysis is the most recent wave of the Encuesta de Estructura Salarial (Structure of Earnings Survey; hereafter, SES). It is a nationally representative survey carried out with a harmonised methodology common to all European Union member countries, making it particularly appropriate for the analysis of wage differentials between certain groups like, e.g., differentials associated with the type of working time. Another remarkable feature of SES is that its matched employer-employee microdata offer abundant information about the characteristics of employees and their jobs and firms. Moreover, given that it is a survey to companies data provided by firms does not suffer from the limitations, widely outlined in literature, of surveys addressed to households, where the self-reported information about wages and working time usually suffers from significant measurement error.

One of the main novelties of our analysis is that it focuses on wage differences observed along the wage distribution for both genders, an aspect that, to our knowledge, has not been examined in previous studies for the Spanish case and that has been examined only scarcely in the international literature, with non-conclusive evidence. Among the main exceptions, Wahlberg (2008) estimates the part-time wage gap in Sweden using quantile regressions and a Swedish register-based dataset with longitudinal individual data (LINDA) to find a negative wage penalty for part-time workers across the whole wage distribution, rather similar for both genders, with a sharp increase of the penalty in the top part of distribution that can be interpreted as evidence of a glass ceiling in part-time employment in the Swedish labour market. In contrast, Tõnurist and Pavlopoulos (2014) find a decreasing wage penalty for part-time workers along the wage distribution in Germany. Lastly, Colella (2014) analyses wage differentials among part-time and full-time working women in a set of European countries. Results from a quantile decomposition approach show noteworthy cross-country differences in their composition and the magnitude of the wage gap. Hence, although part-time wage gaps are observed for women in all of the countries with the exception of Sweden, and they are largely ascribable to differences related to occupation and sector, the pay penalty is wider around the upper limit tail for Spanish women, highlighting a possible "glass ceiling" effect, while for German and French women the wage gap is larger at the lowest part of the percentile distribution, suggesting instead the presence of "sticky floor" mechanisms. 
From a methodological perspective, we apply the econometric decomposition technique proposed by Fortin, Lemieux, and Firpo (2011) to decompose wage differences between part-time and full-time workers by quantiles of the wage distribution. Although this methodology has the advantage over similar techniques that provides a detailed decomposition of wage differentials, it has not been used before in this context. The obtained evidence shows that part-time work tends to penalise low-qualified men located in the lower part of the wage distribution and high-qualified women located in the upper part of the distribution the most.

The rest of the article is structured as follows. In the next section we present the main theoretical hypothesis about wage penalties for part-time workers at different points of the wage distribution. In the third section the database used in the study is presented. In the fourth section we describe the econometric methodology used in the empirical analysis. In the fifth section we present the obtained empirical evidence. Lastly, the article ends with the main conclusions.

\section{Theoretical hypothesis}

\subsection{Part-time wage penalties for men and women}

Theoretical models predict different wage penalties for both genders. In particular, according to the theory of dual labour markets (Doeringer and Piore, 1971), in the secondary segment of the labour market there will be a higher presence of female workers and, taking into account differences in wage levels between the primary and the secondary segment, a gender wage gap will appear. If this duality also holds in part-time jobs, as Tilly (1992) suggests, part-time jobs in the primary segment would be filled by male workers while females would be mostly employed in secondary part-time jobs. As a result, it can be deduced that the wage penalty associated to part-time jobs will be higher between female than between male workers.

The theory of the 'flexibility stigma' (Williams et al, 2013) also poses the existence of a wage penalty on those workers that request a reduction of working time for family or personal reasons, due to the employer's belief that they are less devoted to work and engaged with the firm than the 'ideal' worker. The theory poses the possibility of gender differences since male workers requesting flexibility are seen as less competitive and ambitious and show a reduced commitment (Rudman and Mescher, 2013) and, for this reason, they perceive lower wages and have fewer promotion opportunities than full-time male workers (Coltrane et al., 2013). In the particular case of involuntary part-time males, they could be seen as incompetent, because they do not get the full-time job they want (Pedulla, 2016). Given that the available evidence confirms that the flexibility stigma is more detrimental in practice in the case of part-time male workers than in the case of females as regards the possibility of obtaining call-backs to their job applications (Pedulla, 2016), a higher wage penalty associated to part-time jobs is plausibly expected to be found among male workers according to this theory. 


\subsection{Part-time wage penalties along the wage distribution}

As previously mentioned, the theory of dual labour markets (Doeringer and Piore, 1971) predicts a wage penalty for part-time jobs. As part of the secondary segment of the labour market, wages of part-time workers are lower than full-time ones due to their lower qualifications and their reduced bargaining power, so they will be mainly concentrated in the low tail of the wages distribution, where the wage penalty associated to part-time jobs would be higher. Moreover, as Tilly (1992) argues, part-time jobs can be also separated into two groups: one within the secondary segment (that would be predominant) but also a second one with jobs within the primary segment that would be offered to high qualified workers looking for flexibility in order to retain them. If this case, in this second group of part-time jobs, wage penalty would not exist or could become a positive premium. These jobs would be usually placed in the top tail of the wage distribution. So, according to this theory, the wage penalty associated to part-time jobs could vary along the wage distribution, being higher for lowwage workers.

On the opposite, from the theory of the career mobility (Sicherman and Galor, 1990) it can be deduced that the wage penalty along the wage distribution varies, but in a different way. In particular, according to this theory, the probability of job promotion depends on the ability, schooling and job experience of the workers. Seniority in the firm and in the specific job increases the probability of promotion as experience increases the required skills for an upward transition towards a better job. As part-time jobs limit the capacity of workers to acquire new knowledge and skills, their probability of promotion could be lower for part-time workers than for full-time ones. Moreover, as the probability of promotion also depends positively on schooling, the wage penalty associated to parttime jobs would be higher for more educated workers, so from this theory we can predict an increasing penalty along the wage distribution with a higher penalty for top-wage workers.

\section{Data}

The empirical analysis carried out in this article is based on the matched employer-employee microdata of the most recent wave of the Structure of Earnings Survey (SES), corresponding to 2010. The SES is designed as independent cross-section databases updated every four years by the Spanish National Statistics Institute, and it is Spain's sample for the European Structure of Earnings Survey, a survey carried out in all European Union member countries in accordance with a harmonised methodology. It is a nationally representative survey on firms that covers employees working in the month of October at establishments of any size and whose economic activity is framed in sections B to $\mathrm{S}$ of the sectoral classification NACE 2009. Therefore, it encompasses the bulk of the private sector of the 
Spanish economy, excluding only specific sectors such as agriculture and domestic service. The survey design corresponds to a two-stage sampling of employees working in firms registered in the social security system, and hence one of its most important features is the inclusion of matched employeremployee microdata (i.e., observations for several employees in each establishment). Moreover, it is important to note that it is a survey specifically designed to provide reliable information about the characteristics of the wage distribution in the Spanish labour market.

Regarding the definition of part-time, in the SES each firm indicates the employee's status as full- or part-time depending on his/her hours worked. Specifically, in the case of each worker the firm has to choose between full-time or part-time in response to the following question: '4.1 Type of job.' It is considered part-time if hours worked are less than the normal working day of the firm or, in the absence of a normal working day, if they are lower than the maximum legally set (it must be stipulated in the contract). As regards the rest of variables, the SES provides detailed information on wages and the characteristics of workers (nationality, gender, age, and education); jobs (tenure and type of contract) and firms (sector, size, type of collective agreement and region). The wage concept used in this research is the gross hourly wage, calculated from the wage corresponding to a representative month (October) divided by the number of hours worked in that month. In this calculation, any payment by companies, including commissions, bonuses for night work and weekends, as well as overtime work, has been incorporated.

The analysis is carried out separately for men and women due to the theoretical reasons described in the previous section. Moreover, following most previous studies on the relative wage treatment of part-time workers that limit the analysis to private sector employees, observations corresponding to the public sector (i.e., Section O, Public administration and defence, compulsory social security) have been removed. ${ }^{2}$ Finally, observations with missing values on key variables and those for individuals aged less than 16 years or over 65 years, or with hourly wages less than 2.5 euros or greater than 200 euros have been filtered. The final sample is formed by 152,099 observations, which correspond to 89,344 men (81,578 working full-time and 7,766 part-time) and 62,755 women (45,338 working full-time and 17,417 part-time).

\section{Methodology}

In the empirical analysis, we apply the methodology proposed by Fortin, Lemieux, and Firpo (2011), a technique that enhances the development of the empirical decompositions of differences between two distributions of a variable. This technique provides a breakdown of the differences between distributions in the value of any distributional statistic (as the value of a quantile or an inequality index) based on differences in the endowments of characteristics and in their returns. This

\footnotetext{
2 According to SES data for 2010, the incidence of part-time employment in Spain is much lower in the public sector than in the private both in the case of men (5.3\% compared to $8.7 \%)$ and, especially, of women (10.3 \% compared to $27.7 \%)$.
} 
procedure has considerable advantages compared to techniques previously proposed in the literature, which also permit the decomposition of differences between distributions based on construction of counterfactual distributions (DiNardo, Fortin and Lemieux, 1996; Juhn, Murphy and Pierce, 1993; Machado and Mata, 2005 and Melly, 2005, 2006). Thus, whereas the latter techniques consist of aggregated decompositions, which, aside from partial exceptions, provide exclusively the separate effects on the differential of differences in characteristics and returns, respectively, Fortin, Lemieux, and Firpo's methodology provides a detailed decomposition that allows us to ascertain additionally the individual contribution of each explanatory variable for both components.

This methodology is based on the estimation of a regression in which the independent variable (the wage) is substituted by a transformation of the same, the recentred influence function (RIF). Subsequently, a standard Oaxaca-Blinder decomposition can be developed for any distributional statistic based on the regression results.

The influence function measures the effect on distributional statistics of small changes in the underlying distribution. Thus, for a given distributional statistic of the distribution $F_{W}, v(F)$, this function measures the importance of each observation in shaping its value. Fortin, Lemieux, and Firpo (2011) suggest using a recentred version of the influence function having added the statistic of interest, $R I F(W)=v(F)+I F(W)$, since it has as expected value the actual statistic $v(F)$ (insofar as the expectation of the function of influence with respect to distribution of $W$ is, by definition, zero).

In the case of the quantiles $Q_{\theta}$ of the unconditioned marginal distribution $F_{W}$, the function of influence, $\operatorname{IF}\left(W, Q_{\theta}\right)$, is defined as

$$
I F\left(W / Q_{\theta}\right)=\frac{\theta-l\left\{W<Q_{\theta}\right\}}{f_{W}\left(Q_{\theta}\right)}
$$

where $l\{\cdot\}$ is an indicator function and $f_{W}$ is the function of density of the marginal distribution of $W$ evaluated in $Q_{\theta}$.

Given that the function of recentered influence, $\operatorname{RIF}\left(W, Q_{\theta}\right)$, is equal to $Q_{\theta}+I F\left(W, Q_{\theta}\right)$, then the following is fulfilled:

$$
\operatorname{RIF}\left(W / Q_{\theta}\right)=Q_{\theta}+\frac{\theta-l\left\{W<Q_{\theta}\right\}}{f_{W}\left(Q_{\theta}\right)}
$$

The RIF function may be computed empirically in the case of the quantiles by means of a local inversion following calculation of the dummy variable $l\left\{W<Q_{\theta}\right\}$ (which specifies whether the value $W$ is higher or lower than $Q_{\theta}$ ), the estimation of the quantile of the sample $Q_{\theta}$, and the 
estimation by means of kernel density functions of the corresponding density function $f_{W}$ evaluated in $Q_{\theta}$.

Following calculation of the RIF function for the quantile, a value is provided for the transformed variable for each observation of the sample. Insofar as the effect of the change in distribution of an explanatory variable in the quantile may be expressed ceteris paribus, as the average partial effect of that variable in the conditioned expectation on its RIF function, and assuming that the conditioned expectation of the RIF function may be modelled as a linear function of the explanatory variables, these values may be used for estimation by means of ordinary least squares of a regression of the RIF variable in a vector of explanatory variables. The estimated coefficients of that regression may then be used for calculation of a standard Oaxaca-Blinder decomposition of different quantiles of the distribution. Following the recommendation of Oaxaca and Ransom (1994) and Neumark (1998), the wage structure of the two groups involved in the comparison has been used as the reference wage structure in the development of the decomposition. ${ }^{3}$

Consequently, the decomposition takes the following form:

$$
\Delta_{Q_{\theta}}=\left(\bar{X}^{p}-\bar{X}^{f}\right) \hat{\gamma}_{Q_{\theta}}^{*}+\left\{\bar{X}^{p}\left(\hat{\gamma}_{Q_{\theta}}^{f}-\hat{\gamma}_{Q_{\theta}}^{*}\right)+\bar{X}^{f}\left(\hat{\gamma}_{Q_{\theta}}^{*}-\hat{\gamma}_{Q_{\theta}}^{p}\right)\right\}
$$

Wherein $\Delta_{Q_{\theta}}$ is the difference in the quantile $Q_{\theta}$ of the wage distributions of part- and full-time workers, respectively; $\bar{X}^{p}$ and $\bar{X}^{f}$ are the average observed characteristics for part- and full-time workers, and $\hat{\gamma}_{Q_{\theta}}^{p}, \hat{\gamma}_{Q_{\theta}}^{f}$ and $\hat{\gamma}_{Q_{\theta}}^{*}$ are the estimated coefficients following regression of the RIF variable of the quantile $Q_{\theta}$ on the group of explanatory variables for part-time workers, full-time workers, and the pool of both groups respectively. The first component of the right-hand side of the equation represents the effect on the differential between distributions caused by differences in characteristics (or the 'explained' component), whereas the second corresponds to the effect of the coefficients (or 'unexplained' component). As previously referenced, the contribution of each explanatory factor through each of the two components can be observed in the decomposition results.

\section{Results}

\subsection{Descriptive evidence}

Table 1 provides information on the raw wage differential between part-time and full-time workers, measured as the logarithm of the wage per hour and distinguishing between male and female

\footnotetext{
3 Although the use of other reference wage structures could lead to different results (for details on the 'index number problem' see Oaxaca and Ransom, 1994), the evidence obtained using as an alternative reference wage structure that for full-time workers is qualitatively similar. These results are available from the authors on request.
} 
workers. A negative value (positive) of the differential corresponds to a wage disadvantage (advantage) of part-time workers. We observe that in Spain there is a significant negative average wage differential for part-time workers, although the gap is substantially lower in the case of men (the average value is of -0.104 logarithmic points) than of women (with an average gap of -0.254 logarithmic points). The wage differential, on the other hand, is not homogeneous along the wage distribution given that in the case of male workers the differential tends to decrease along the distribution, particularly in its right tail (until the point to be favourable for part-time workers in the right tail of the distribution), whereas in the case of females the differential increases along it.

Tables A.1 and A.2 of the Appendix present descriptive statistics of the sample used in the empirical analysis, distinguishing between male and female workers and by the different quartiles of the wage distribution. According to these figures, there are significant differences in the characteristics of full-time and part-time workers, although these differences vary between male and female workers. In particular, in the case of female workers those working part-time present in general characteristics usually associated with lower wages: namely, higher presence of immigrants; lower average educational levels and seniority in firms; greater incidence of fixed-term contracts; less presence in high-wage sectors like manufacturing and construction; and higher presence in small firms without specific collective agreements. In the case of male part-time workers, although some characteristics are clearly unfavourable to their relative wages (e.g., higher presence of immigrants; lower seniority; a greater incidence of fixed-term contracts; higher presence in the service sector and in firms without specific collective agreements), other characteristics have the opposite effect (e.g., older and seniority). This last circumstance is mainly explained by the characteristics of males in the high part of the wage distribution, as better endowments of those variables are, in fact, only observed for part-time workers in the upper part of the distribution. Let us note that this finding is consistent with the fact that a significant portion of job contracts among part-time male workers in Spain are related to partial retirement and affect, hence, to individuals with greater age and seniority (Muñoz de Bustillo et al., 2008). 


\subsection{Econometric results}

Figures 1 and 2 show the results of the decomposition of wage differences between part- and full-time male and female Spanish workers by quantiles of the wage distribution obtained after applying the methodology proposed by Fortin, Lemieux, and Firpo (2011). The evidence has been obtained from a specification of the wage equation (1) that includes socio-demographic individual characteristics and job and firm attributes. The former are controls relating to the nationality of the individual (differentiating between natives and immigrants); the level of general education (distinguishing three levels: primary, secondary, and tertiary education) and age. The characteristics of the job are years of seniority in the current job (including its quadratic form) and type of contract (indefinite or fixed-term), ${ }^{4}$ while attributes of the firms are sector (12 categories corresponding to sections of the classification NACE-93); size (four categories); type of collective agreement (distinguishing between firm, national sector, and subnational sector agreements) and region of location of the firm (there are 17 regions in Spain).

To facilitate the presentation, figure 1 distinguishes between the aggregated contribution to the wage differential of differences in characteristics and returns (the latter term corresponding hence to the wage penalty associated to part-time work), whereas figure 2 shows the detailed results of the separate effect of each explanatory variable included in equation (1) associated with the characteristics component. ${ }^{5}$ Variables have been grouped in this last figure according to three categories (individual, job and firms characteristics, respectively) to facilitate interpretation of the influence of individual explanatory variables on characteristics component. Additional information on the results of the decomposition can be found in tables 2 and 3. In particular, the first two rows of both tables show the log hourly wages of part- and full-time workers in different quantiles of the distribution (i.e. 1.692 in Table 2 is the $\log$ hourly wages of part-time male workers in the $10^{\text {th }}$ percentile); the third row shows the value of the raw differential in log hourly wages between part- and full-time workers in the quantiles of the distribution, whereas the next two rows show the value of the characteristics and coefficient terms of the decomposition (where a negative value indicates that the factor has a negative effect on the relative wages of part-time workers). The rest of the rows in the table show the specific impact of each of the individual explanatory variables on the characteristics component, including both the contribution in absolute terms and as a percentage of the total difference.

In the case of male workers, aggregate results of the econometric decomposition (upper panel of figure 1) show that the wage disadvantage associated with part-time jobs observed in the left and

\footnotetext{
${ }^{4}$ The SES also includes information on occupation. However, this variable has not been considered in the analysis, given that it potentially suffers from endogeneity in relation to the distribution of individuals between full- and part-time jobs, to the extent that part-time employment is often limited to low-wage occupations (for details, see Manning and Petrongolo, 2008).

${ }^{5}$ Estimated coefficients by means of unconditional quantile regressions required for the decomposition are available from the authors on request.
} 
in the medium part of the distribution is due both to the worst endowment of characteristics of individuals with part-time contracts (i.e. the characteristics component) and the presence of a relative wage penalty (coefficients component). Moreover, the reduction of the wage gap observed particularly in the right part of the wage distribution is mainly due to the fact that the wage penalty reduces significantly its intensity in that part of the distribution (until a point where it becomes a wage premium for the last two deciles).

As regards the detailed results related to the characteristics component (upper panel of figure 2 and table 2), although differences in individual, job and firm characteristics are in all cases relevant origins of the wage disadvantage of part-time male workers, differences in job characteristics such as tenure and the incidence of fixed-term contracts are in particular the most important individuals contributors (note that these two aspects are clearly interrelated as the high job turnover due to the high share of fixed-term contracts in the Spanish labour market implies that many workers are not able to accumulate long periods of on-the-job experience). On the other hand, the slowly increasing profile along the distribution of the overall characteristics component is a result that is essentially explained by the change of sign of the effect of the type of contract (which reflects that there is a relatively higher incidence of permanent contracts in the case or part-time workers in the right tail of the distribution, in contrast with what is observed in the rest of the wage distribution) and the growing impact of the age variable, in the case of individual characteristics (reflecting that individuals located in the right tail of the distribution tend to be relatively older).

In the case of women, the aggregate evidence in the lower panel of figure 1 confirms that differences in endowments of characteristics are systematically the main driver of the lower wages of part-time female workers along the wage distribution. However, the influence of this factor is not homogenous along the distribution, as it is comparatively more reduced in the left tail and grows significantly along it. Although with a less steeper profile, the contribution of the component associated with coefficients also shows an increasing trend along the wage distribution.

Focusing now on the detailed results of the decomposition of the characteristics component, they reveal that differences in the endowments of individual, job and firm characteristics are also in this case relevant origins of the wage disadvantage of part-time workers (figure 2 and table 3 ). The particular domains that are especially harmful for the relative wages of part-time female workers are their lower tenure and, especially, education and their higher presence in low-wage sectors. Moreover, the increasing profile of the characteristics component is explained by the increasing importance of these three elements, since differences in sectoral distribution and in the endowments of tenure, and, particularly, education are very important and especially negative for female workers in the right tail of the distribution (as a matter of example, in the $90^{\text {th }}$ percentile of the distribution they roughly explain all the influence of the characteristics component and about $70 \%$ of the total raw gap). This 
finding suggests, hence, that although the relative segregation into low-wage sectors also plays a role, one of the main drivers of the wage disadvantage of part-time work females is their lower endowments of human capital.

Last, and moving to the wage penalties captured by the coefficients component, the obtained evidence shows that the wage penalty for part-time male workers is higher than for females in most part of the wage distribution. This result seems to confirm the predictions derived by Pedulla (2016) from the 'flexibility stigma' theory for involuntary part-time male workers.

According to the obtained results, the wage penalty for male part-time workers compared to full-time male workers is higher in the bottom than in the top part of the wage distribution. In particular, it reduces with more intensity after the sixth decile and it becomes a wage premium after the ninth decile. This result can be explained by the fact that the Spanish legislation allows workers older than 60 to work part-time without any loss of acquired rights as a previous step to retirement. ${ }^{6}$ On the other hand, our results regarding the wage penalty for male part-time workers confirm the predictions derived from the segmentation theory and, in particular, the existence of a primary segment within part-time jobs as suggested by Tilly (1992). The evidence is also similar to the one found by Tönurist and Pavlopoulos (2014) for Germany, but opposite to the evidence for Swedish men by Wahlberg (2008).

In the case of women, we have found a wage penalty that is relatively stable until the fourth decile when it clearly increases achieving the maximum at the top part of the wage distribution. As opposite to males, these results are consistent with the conclusions derived from the theory of career mobility: an increasing penalty along the wage distribution and higher for women in the right part of the distribution (which, on the other hand, are those more qualified, with more years of experience, higher schooling, and higher levels of seniority: for detailed evidence see table A.2). This higher penalty for more qualified and educated women is in line with two phenomena highlighted in the empirical literature. On one hand, the returns to schooling years could be relatively lower as the transition from full-time to part-time work usually involves occupational downgrading (Connolly and Gregory, 2009), particularly in those countries, like Spain, where the law does not contemplate the right of the employee to keep the same job when reducing working time. ${ }^{7}$ Additionally, those who work part-time have a lower probability of being promoted in the firm (Russo and Hassik, 2008) and show less wage progress when they achieve it (Wolf, 2014 and Fernández-Kranz and Rodríguez-

\footnotetext{
${ }^{6}$ Moreover, Pérez et al. (2015) have also found evidence of a complementarity or shared leisure effect for older males in Spain. In particular, their results show that wife's employment leads the husband to remain active in the labour market. So, part-time work can be a good option for older males while their wives still participate in the labour market.

${ }^{7}$ In countries like Norway, the Netherlands, Sweden, Germany or France the worker can change to part-time status with neither loss of category nor responsibility, except in determinate circumstances, which minimises the risk of occupational downgrading. In the UK, where this possibility does not exist, Connolly and Gregory (2009) found that $25.6 \%$ of the women that opt by part-time jobs suffer occupational downgrading, representing an hourly wage decrease of $32 \%$.
} 
Planas, 2011). As career mobility highlights, these factors affect, in greater measure, those who have more schooling(more degradation) and more years of potential experience (more lost promotions). ${ }^{8}$

Our results are in line with the evidence found by Wahlberg (2008) for Swedish women and by Colella (2014) for Italian women. Colella (2014) also founds that for Dutch women the penalty increases in the bottom and in the top part of the distribution (inverse U-shaped). The same author finds that in Germany and France the penalty for females decrease or even becomes a positive premium in the top deciles of the wage distribution.

\section{Conclusions}

This article examines wage differentials between part-time and full-time workers in Spain distinguishing by gender. Our analysis contributes to the literature by considering differences along the wage distribution, given that previous evidence on this issue is non-existent for Spain and is rather scarce for other advanced countries. We consider that Spain is an interesting analysis case from an international perspective given the significant increase of part-time work during the last years, but especially because in contrast with most other advanced countries a majority of part-time employment in Spain is involuntary both for males and females.

The research is based on cross-section matched employer-employee microdata from a large representative survey (the Encuesta de Estructura Salarial) which is carried out with a harmonised methodology common to all European Union member countries and that covers almost exhaustively the private sector in Spain. The survey has been designed specifically to provide reliable evidence about characteristics of the wage distribution such us wage differentials associated with the type of working time. On the other hand, from a methodological point of view, we apply the econometric decomposition technique proposed recently by Fortin, Lemieux, and Firpo (2011) to decompose wage differences between part-time and full-time workers by quantiles of the wage distribution. This methodology has the advantage over similar techniques that provides a detailed decomposition of wage differentials and has not been used before to examine this topic.

The evidence for Spain shows that the wage disadvantage associated with part-time work differs substantially along the wage distribution, increasing for women and decreasing for men (until the point at which in the latter case it vanishes in the right tail of the distribution). Results from the decompositions suggest that in the case of part-time females the wage disadvantage is mostly

\footnotetext{
${ }^{8}$ Unlike female workers, these phenomena are not observed for male workers. In fact, the returns to experience do not have the same negative impact for males. The most reasonable explanation is that in a lot of cases these workers change to part-time jobs after several years of full-time dedication, having accumulated specific human capital at the same level as other full-time workers. Men's returns to education do not have the same penalty as for women, reflecting the absence of occupational downgrading although working part-time - a result that is in line with the fact that there is a significant proportion of advanced age men who access a partial retirement, without changing firms or occupations.
} 
explained by their relative endowments of characteristics, given that part-time female workers present in general characteristics associated with lower wages. The detailed results obtained via the econometric decomposition suggest that the particular domains that are especially harmful for the relative wages of part-time female workers are their lower endowments of human capital (i.e. tenure and, especially, education) and their segregation into low-wage sectors. Yet, even after having controlled for differences in characteristics a wage penalty for female part-time workers still persists with an increasing profile along the wage distribution. The female wage penalty profile confirms the prediction derived from the career mobility hypothesis. In the case of males the wage disadvantage of part-time workers observed in the lower part of the distribution is due both to their relatively worse endowments of characteristics (with a particularly relevant influence of job characteristics such as a lower tenure or a higher incidence of fixed-term contracts) and a significant wage penalty, , confirming the hypothesis derived from the segmentation theory. Yet, in the upper part of the distribution the wage penalty vanishes, very probably due to the existence of part-time job contracts related to partial retirement with all acquired rights which tend to affect more to males with higher wages. Overall, hence, our evidence for Spain seems to indicate that part-time work tends to affect differently to the wages of males and females, with a higher penalty for part-time males, as predicted by the 'flexibility stigma' theory, and penalising low-qualified men located in the lower part of the wage distribution and high-qualified women located in the upper part of the distribution the most.

\section{References}

Belous, R. (1989): The Contingent Economy: The Growth of the Temporary, Part-Time and Subcontracted Workforce, National Planning Association, Washington, DC.

Cebrián, I., V. Gash, G. Moreno, P. O’Connell and L. Toharia (2000): "Pheripheral labour in peripheral markets? Mobility and working time within transitional labour markets among women in Ireland and Spain” in O'Reilly, I. Cebrián and M. Lallement (eds.), Working-Time Changes. Social Integration Trough Transitional Labour Markets, Edward Edgar, pp. 205-250.

Cebrián, I., G. Moreno and L. Toharia (2001) "Trabajo a tiempo parcial y duración de la jornada en la Unión Europea: Características, salarios, pobreza", in INE: Condiciones de vida en España y en Europa, INE, Madrid, pp. 241-280.

Colella, F. (2014), Women's Part-Time - Full-Time Wage Differentials in Europe: an Endogenous Switching Model, MPRA Paper No. 56735.

Coltrane, S., E. Miller, T. DeHaan, and L. Stewart (2013), "Fathers and the Flexibility Stigma", Journal of Social Issues, 69 (2), pp. 279-302.

Connolly, S. and M. Gregory (2009): “The part-time pay penalty: earnings trajectoris of British Women”, Oxford Economic Papers 61 (2009), i76-i97.

Di Nardo, J.; Fortin, N.M. and T. Lemieux. (1996): "Labor market institutions and the distribution of wages, 1973-1992: A semi-parametric approach", Econometrica, 64 (5), pp. 1011-1044.

Doeringer, P. and M. Piore (1971), Internal Labor Markets and Manpower Analysis, Lexington, Massachusetts, D.C. Heath and Company.

Fernández-Kranz, D. and N. Rodríguez-Planas (2010): "El contrato a tiempo parcial”, Papeles de Economía Española, Vol. 124, pp. 148-163.

Fernández-Kranz, D. and N. Rodríguez-Planas (2011): “The part-time penalty in a segmented labor marked”, Labour Economics, 18, pp 591-606. 
Fernández-Kranz, D.; Paul, M. and Rodríguez-Planas, N. (2014): "Part-Time Work, Fixed-Term Contracts, and the Returns to Experience", Oxford Bulletin of Economics and Statistics, forthcoming, http://dx.doi.org/10.1111/obes.12073.

Fortin, N.; Lemieux, T. and Firpo, S. (2011): "Decomposition Methods in Economics", Handbook of Labor Economics, Vol. 4, Chapter 1, pp. 1-102. Elsevier.

Gimm, J. and S. Arber (1998): “How Does Part-Time Work Lead to Low Pension Income?” en O’Reilly, J.y C. Fagan (eds.), Part-Time Prospects: An International Comparison of Part-Time Work in Europe, North America, and the Pacific Rim, Routledge, pp. 156-173.

Hirsch, B.T. (2005): "Why do Part-Time Workers Earn Less? The Role of Workers and Job Skills", Industrial and Labor Relations Review, Vol. 58, No. 4, pp. 525-551.

Houseman, S. and O. Machiko (1998): "What is the Nature of Part-Time Work in the United States and Japan?" en O’Reilly, J.y C. Fagan (eds.), Part-Time Prospects: An International Comparison of Part-Time Work in Europe, North America, and the Pacific Rim, Routledge, pp. 232-251.

Juhn, C.; Murphy, K. and B. Pierce (1993): "Wage inequality and the rise in returns to skill", Journal of Political Economy, Vol. 101, pp. 410-442.

Machado, J. and J. A. F. Mata (2005): "Conterfactual decomposition of changes in wage distributions using quantile regression", Journal of Applied Econometrics, 20 (4), pp. 445-465.

Manning, A. and B. Petrongolo (2008): “The Part-time Pay Penalty for Women in Britain”, Economic Journal, Vol. 118, No. 526, F28-F51.

Melly, B. (2005): "Decomposition of differences in distribution using quantile regression", Labour Economics, Elsevier, 12 (4), pp. 577-590.

Melly, B. (2006): "Estimation of counterfactual distributions using quantile regression", mimeo, Swiss Institute for International Economics and Applied Economic Research, University of St. Gallen.

Muñoz de Bustillo, R., E. Fernández and J.I. Antón (2008): El trabajo a tiempo parcial en España en el contexto de la Unión Europea. Características, condiciones de trabajo y perspectivas, Ministerio de Trabajo e Inmigración, Colección Informes y Estudios, Serie Empleo no 36, Madrid.

Neumark, D. (1988): "Employer's discriminatory behaviour and the estimation of wage discrimination", Journal of Human Resources, Vol. 23, pp. 279-295.

Oaxaca, R. and M. Ransom (1994): "On discrimination and the decomposition of wage differentials", Journal of Econometrics, 61, pp. 5-22.

O'Connell, P.J. and V. Gash (2003): “The Effects of Working Time, Segmentation and Labour Market Mobility on Wages and Pensions in Ireland", British Journal of Industrial Relations 41, pp. 71-95.

O'Dorchai, S., R. Plasman and F. Rycx, (2007): "The part-time wage penalty in European countries: how large is it for men?", International Journal of Manpower, Vol. 28, No 7 pp. 571-603.

OECD (2015): OECD Skills Strategy Diagnostic Report. Spain 2015.

Pagán, R. (2007): "Diferencias salariales entre el empleo a tiempo completo y parcial", Revista de Economía Aplicada, 15(43), pp. 5-48.

Pedulla, D. (2016), "Penalized or Protected? Gender and the Consequences of Nonstandard and Mismatched Employment Histories", American Sociological Review, 81 (2), pp. 262-289.

Pérez, C., Martín-Román, Á. and A. Moral (2015), “The impact of leisure complementarity on the labour force participation of older males in Spain”, Applied Economics Letters, 22 (3), 214-217.

Pissarides, C.; P. Garibaldi; C. Olivetti, B. Petrongolo and E. Wasmer (2005): "Women in the labor force: How well is Europe doing?” in T. Boeri, D. Del Boca and C. Pissarides (eds.), Women at Work: An Economic Perspective, Oxford University Press, pp. 9-120.

Rudman, L. and K. Mescher (2013), "Penalizing Men Who Request a Familily Leave: Is Flexibility Stigma a Feminity Stigma?", Journal of Social Issues, 69 (2), pp. 322-340.

Russo, G. and W. Hassink (2008): “The Part-Time Wage Gap: A Career Perspective”, De Economist, Vol. 156, No. 2, pp. 145-74.

Sicherman, N. and O. Galor (1990), “A Theory of Career Mobility”, Journal of Political Economy, 98 (1), pp. 169192.

Tilly, C. (1990): Short Hours, Short Shrift: Causes and Consequences of Part-Time Work, The Economic Policy Institute, Washington, DC.

Tõnurist, P., Pavlopoulos, D. (2014), Part-Time Wage-Gap in Germany: Evidence across the Wage Distribution, AMCIS Working Paper 2014/2.

Wahlberg, R. (2008) Part-time penalty in Sweden: evidence from a quantile regression. Working paper in Economics No. 315, Gothenburg University, Gothenburg 
Williams, J., M. Blair-Loy and J. Berdahl (2013), "Cultural Schemas, Social Class, and the Flexibility Stigma", Journal of Social Issues, 69 (2), pp. 209-234.

Wolf, E.(2014): The German part-time wage gap: bad news for men?, SOEP papers 663/2014.

\section{Figures and tables}

Figure 1.

Aggregate decomposition of wage differentials between part- and full-time employees. Fortin-LemieuxFirpo decomposition. Males (upper panel) and females (lower panel).
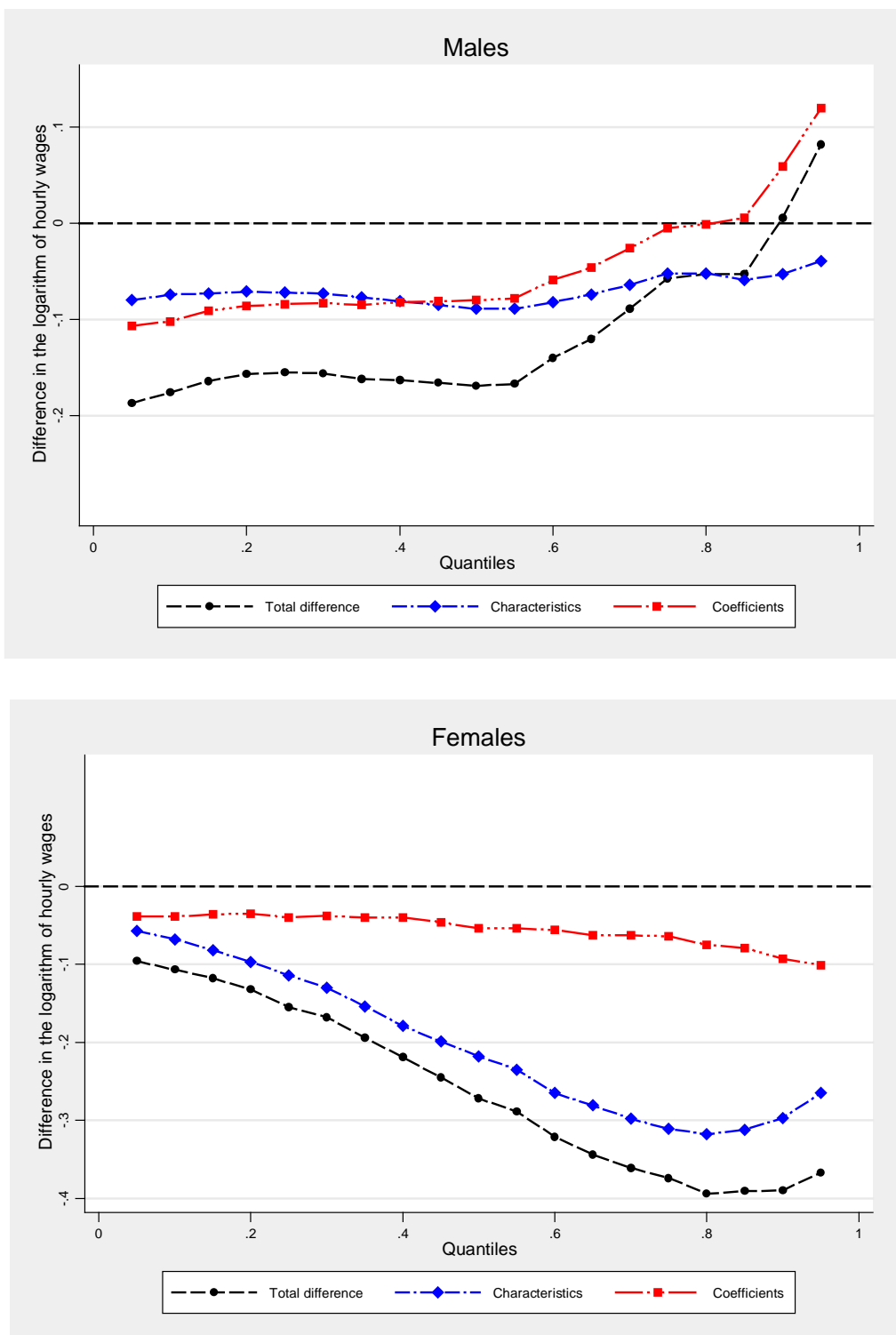

Notes: Individual characteristics and job and firm attributes have been considered as explanatory variables. 
Figure 2.

Detailed decomposition of wage differentials between part- and full-time employees. Fortin-LemieuxFirpo decomposition. Males (upper panel) and females (lower panel).
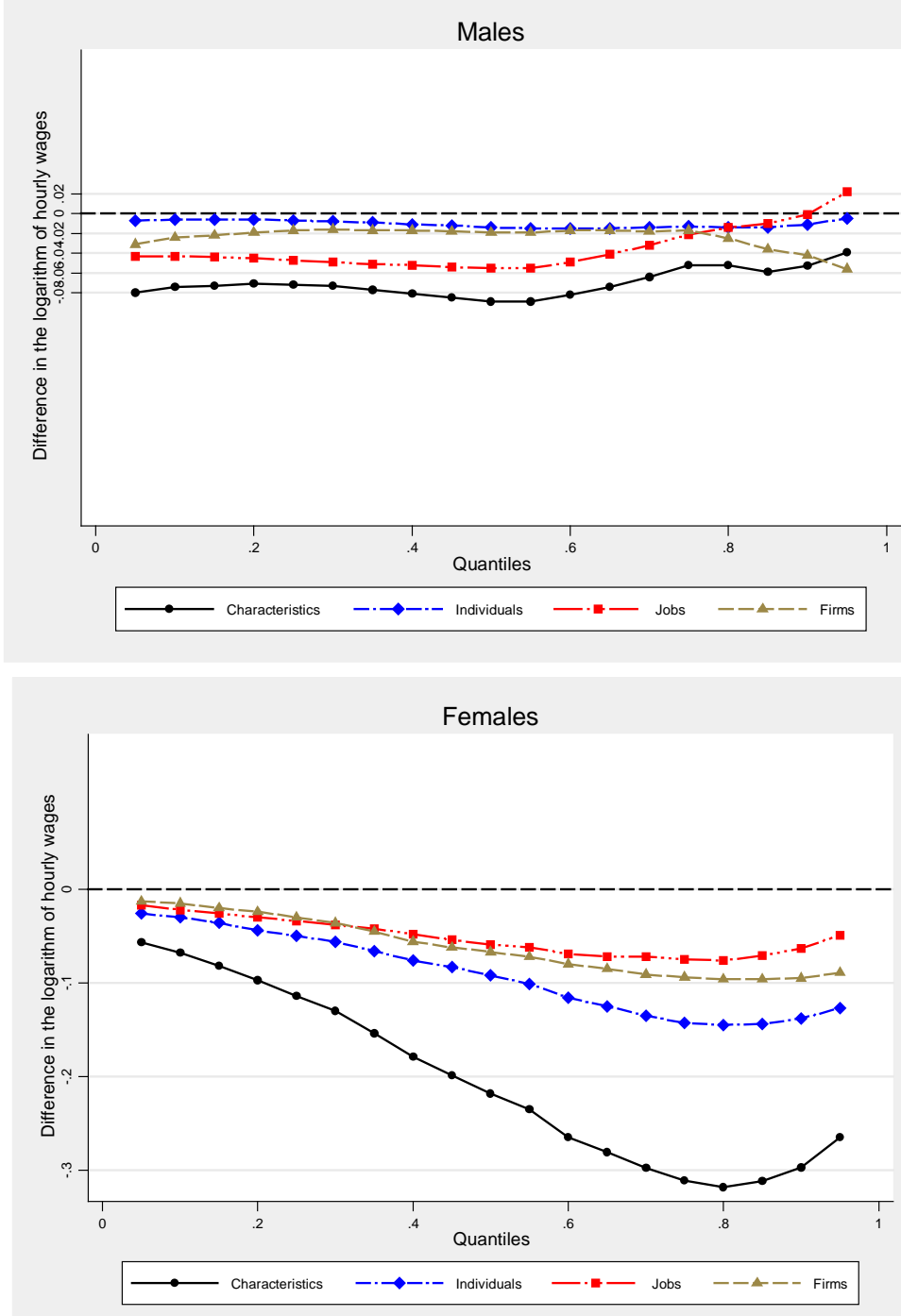

Notes: Individual characteristics and job and firm attributes have been considered as explanatory variables. 
Table 1.

Wage differentials between part- and full-time workers in Spain.

\begin{tabular}{lcc}
\hline & Males & Females \\
\hline $\begin{array}{l}\text { Average } \\
\text { Percentiles }\end{array}$ & -0.104 & -0.254 \\
5 & & \\
10 & -0.191 & -0.099 \\
20 & -0.178 & -0.112 \\
30 & -0.160 & -0.137 \\
40 & -0.165 & -0.176 \\
50 & -0.159 & -0.219 \\
60 & -0.155 & -0.266 \\
70 & -0.125 & -0.319 \\
80 & -0.099 & -0.358 \\
90 & -0.080 & -0.388 \\
95 & -0.016 & -0.391 \\
\hline
\end{tabular}

Notes: The wage gap corresponds to the differential of the logarithm of the hourly wage. 
Table 2.

Decomposition of wage differentials between part- and full-time workers. Fortin-Lemieux-Firpo decomposition. Males.

\begin{tabular}{|c|c|c|c|c|c|c|c|c|c|c|c|}
\hline & & \multicolumn{8}{|c|}{ Quantiles } & \multicolumn{2}{|c|}{ 90th perc. } \\
\hline \multirow[t]{8}{*}{ Total } & Part-time & 1.692 & & 1.896 & & 2.176 & & 2.663 & & 3.090 & \\
\hline & & $(0.006) * * *$ & & $(0.005)^{* * *}$ & & $(0.006)^{* * *}$ & & $(0.013)^{* * *}$ & & $(0.019)^{* * *}$ & \\
\hline & Full-time & 1.867 & & 2.051 & & 2.345 & & 2.720 & & 3.084 & \\
\hline & & $(0.001)^{* * *}$ & & $(0.001)^{* * *}$ & & $(0.002)^{* * *}$ & & $(0.003)^{* * *}$ & & $(0.004)^{* * *}$ & \\
\hline & Difference & -0.176 & & -0.155 & & -0.169 & & -0.057 & & 0.006 & \\
\hline & & $(0.006)^{* * *}$ & & $(0.005)^{* * *}$ & & $(0.006)^{* * *}$ & & $(0.013)^{* * *}$ & & -0.02 & \\
\hline & Characteristics & $\begin{array}{l}-0.074 \\
(0.002)^{* * *}\end{array}$ & $42.0 \%$ & $\begin{array}{l}-0.072 \\
(0.003)^{* * *}\end{array}$ & $46.5 \%$ & $\begin{array}{l}-0.089 \\
(0.004)^{* * *}\end{array}$ & $52.7 \%$ & $\begin{array}{l}-0.052 \\
(0.007)^{* * *}\end{array}$ & $91.2 \%$ & $\begin{array}{l}-0.053 \\
(0.009)^{* * *}\end{array}$ & $-883.3 \%$ \\
\hline & Coefficients & $\begin{array}{l}-0.102 \\
(0.005)^{* * *}\end{array}$ & $58.0 \%$ & $\begin{array}{l}-0.084 \\
(0.004)^{* * *}\end{array}$ & $54.2 \%$ & $\begin{array}{l}-0.080 \\
(0.005)^{* * *}\end{array}$ & $47.3 \%$ & $\begin{array}{l}-0.005 \\
(0.010)\end{array}$ & $8.8 \%$ & $\begin{array}{l}0.059 \\
(0.016)^{* * *}\end{array}$ & $983.3 \%$ \\
\hline \multirow[t]{9}{*}{ Characteristics } & Nationality & $\begin{array}{l}-0.002 \\
(0.000) * * *\end{array}$ & $1.1 \%$ & $\begin{array}{l}-0.002 \\
(0.000)^{* * *}\end{array}$ & $1.3 \%$ & $\begin{array}{l}-0.003 \\
(0.000)^{* * *}\end{array}$ & $1.8 \%$ & $\begin{array}{l}-0.000 \\
(0.000)\end{array}$ & $0.0 \%$ & $\begin{array}{l}0.002 \\
(0.000)^{* * *}\end{array}$ & $33.3 \%$ \\
\hline & Age & $\begin{array}{l}0.002 \\
(0.000) * * *\end{array}$ & $-1.1 \%$ & $\begin{array}{l}0.004 \\
(0.000)^{* * *}\end{array}$ & $-2.6 \%$ & $\begin{array}{l}0.008 \\
(0.001)^{* * *}\end{array}$ & $-4.7 \%$ & $\begin{array}{l}0.020 \\
(0.002)^{* * *}\end{array}$ & $-35.1 \%$ & $\begin{array}{l}0.029 \\
(0.003)^{* * *}\end{array}$ & $483.3 \%$ \\
\hline & Education & $\begin{array}{l}-0.006 \\
(0.001)^{* * *}\end{array}$ & $3.4 \%$ & $\begin{array}{l}-0.009 \\
(0.001)^{* * *}\end{array}$ & $5.8 \%$ & $\begin{array}{l}-0.019 \\
(0.002)^{* * *}\end{array}$ & $11.2 \%$ & $\begin{array}{l}-0.033 \\
(0.003)^{* * *}\end{array}$ & $57.9 \%$ & $\begin{array}{l}-0.042 \\
(0.004)^{* * *}\end{array}$ & $-700.0 \%$ \\
\hline & Tenure & $\begin{array}{l}-0.018 \\
(0.001)^{* * *}\end{array}$ & $10.2 \%$ & $\begin{array}{l}-0.019 \\
(0.001)^{* * *}\end{array}$ & $12.3 \%$ & $\begin{array}{l}-0.022 \\
(0.002)^{* * *}\end{array}$ & $13.0 \%$ & $\begin{array}{l}-0.009 \\
(0.003)^{* * *}\end{array}$ & $15.8 \%$ & $\begin{array}{l}-0.012 \\
(0.004)^{* * *}\end{array}$ & $-200.0 \%$ \\
\hline & Contract & $\begin{array}{l}-0.025 \\
(0.002)^{* * *}\end{array}$ & $14.2 \%$ & $\begin{array}{l}-0.028 \\
(0.001)^{* * *}\end{array}$ & $18.1 \%$ & $\begin{array}{l}-0.033 \\
(0.002)^{* * *}\end{array}$ & $19.5 \%$ & $\begin{array}{l}-0.012 \\
(0.003)^{* * *}\end{array}$ & $21.1 \%$ & $\begin{array}{l}0.011 \\
(0.004)^{* * *}\end{array}$ & $183.3 \%$ \\
\hline & Region & $\begin{array}{l}0.005 \\
(0.001)^{* * *}\end{array}$ & $-2.8 \%$ & $\begin{array}{l}0.006 \\
(0.001)^{* * *}\end{array}$ & $-3.9 \%$ & $\begin{array}{l}0.009 \\
(0.001)^{* * *}\end{array}$ & $-5.3 \%$ & $\begin{array}{l}0.010 \\
(0.001)^{* * *}\end{array}$ & $-17.5 \%$ & $\begin{array}{l}0.008 \\
(0.001)^{* * *}\end{array}$ & $133.3 \%$ \\
\hline & Sector & $\begin{array}{l}-0.028 \\
(0.001)^{* * *}\end{array}$ & $15.9 \%$ & $\begin{array}{l}-0.023 \\
(0.001)^{* * *}\end{array}$ & $14.8 \%$ & $\begin{array}{l}-0.032 \\
(0.001)^{* * *}\end{array}$ & $18.9 \%$ & $\begin{array}{l}-0.039 \\
(0.002)^{* * *}\end{array}$ & $68.4 \%$ & $\begin{array}{l}-0.060 \\
(0.003)^{* * *}\end{array}$ & $-1000.0 \%$ \\
\hline & Size & $\begin{array}{l}0.000 \\
(0.001)\end{array}$ & $0.0 \%$ & $\begin{array}{l}-0.001 \\
(0.001)\end{array}$ & $0.6 \%$ & $\begin{array}{l}0.001 \\
(0.001)\end{array}$ & $-0.6 \%$ & $\begin{array}{l}0.005 \\
(0.001)^{* * *}\end{array}$ & $-8.8 \%$ & $\begin{array}{l}0.005 \\
(0.001)^{* * *}\end{array}$ & $83.3 \%$ \\
\hline & Collective agreement & $\begin{array}{l}-0.001 \\
(0.000) * * *\end{array}$ & $0.6 \%$ & $\begin{array}{l}0.001 \\
(0.000)^{* *}\end{array}$ & $-0.6 \%$ & $\begin{array}{l}0.003 \\
(0.001)^{* * *}\end{array}$ & $-1.8 \%$ & $\begin{array}{l}0.007 \\
(0.001)^{* * *}\end{array}$ & $-12.3 \%$ & $\begin{array}{l}0.005 \\
(0.001)^{* * *}\end{array}$ & $83.3 \%$ \\
\hline$N$ & & 89.344 & & 89.344 & & 89.344 & & 89.344 & & 89.344 & \\
\hline
\end{tabular}

Notes: The right part of each column contains the contribution of each characteristic as a percentage of the total difference in hourly wages between part- and full-time workers.

$* p<0,1 ; * * p<0,05 ; * * * p<0,01$ 
Table 3.

Decomposition of wage differentials between part- and full-time workers. Fortin-Lemieux-Firpo decomposition. Males.

\begin{tabular}{|c|c|c|c|c|c|c|c|c|c|c|c|}
\hline & & \multicolumn{10}{|c|}{ Quantiles } \\
\hline \multirow[t]{8}{*}{ Total } & Part-time & 1.616 & & 1.760 & & 1.944 & & 2.215 & & 2.557 & \\
\hline & & $(0.003)^{* * *}$ & & $(0.003)^{* * *}$ & & $(0.003)^{* * *}$ & & $(0.005)^{* * *}$ & & $(0.009)^{* * *}$ & \\
\hline & Full-time & 1.724 & & 1.915 & & 2.216 & & 2.590 & & 2.948 & \\
\hline & & $(0.002)^{* * *}$ & & $(0.002)^{* * *}$ & & $(0.003)^{* * *}$ & & $(0.004)^{* * *}$ & & $(0.005)^{* * *}$ & \\
\hline & Difference & -0.107 & & -0.155 & & -0.272 & & -0.374 & & -0.390 & \\
\hline & & $(0.003)^{* * *}$ & & $(0.003)^{* * *}$ & & $(0.004) * * *$ & & $(0.007)^{* * *}$ & & $(0.010)^{* * *}$ & \\
\hline & Characteristics & $\begin{array}{l}-0.068 \\
(0.002)^{* * *}\end{array}$ & $63.6 \%$ & $\begin{array}{l}-0.114 \\
(0.002)^{* * *}\end{array}$ & $73.5 \%$ & $\begin{array}{l}-0.218 \\
(0.003)^{* * *}\end{array}$ & $80.1 \%$ & $\begin{array}{l}-0.311 \\
(0.004)^{* * *}\end{array}$ & $83.2 \%$ & $\begin{array}{l}-0.297 \\
(0.005) * * *\end{array}$ & $76.2 \%$ \\
\hline & Coefficients & $\begin{array}{l}-0.039 \\
(0.003)^{* * *}\end{array}$ & $36.4 \%$ & $\begin{array}{l}-0.040 \\
(0.003)^{* * *}\end{array}$ & $25.8 \%$ & $\begin{array}{l}-0.054 \\
(0.004)^{* * *}\end{array}$ & $19.9 \%$ & $\begin{array}{l}-0.064 \\
(0.005)^{* * *}\end{array}$ & $17.1 \%$ & $\begin{array}{l}-0.093 \\
(0.009)^{* * *}\end{array}$ & $23.8 \%$ \\
\hline \multirow[t]{9}{*}{ Characteristics } & Nationality & $\begin{array}{l}-0.001 \\
(0.000)^{* * *}\end{array}$ & $0.9 \%$ & $\begin{array}{l}-0.002 \\
(0.000)^{* * *}\end{array}$ & $1.3 \%$ & $\begin{array}{l}-0.001 \\
(0.000)^{* * *}\end{array}$ & $0.4 \%$ & $\begin{array}{l}0.001 \\
(0.000)^{* * *}\end{array}$ & $-0.3 \%$ & $\begin{array}{l}0.003 \\
(0.000)^{* * *}\end{array}$ & $-0.8 \%$ \\
\hline & Age & $\begin{array}{l}-0.000 \\
(0.000)\end{array}$ & $0.0 \%$ & $\begin{array}{l}-0.000 \\
(0.000)\end{array}$ & $0.0 \%$ & $\begin{array}{l}0.000 \\
(0.000)\end{array}$ & $0.0 \%$ & $\begin{array}{l}0.000 \\
(0.000)\end{array}$ & $0.0 \%$ & $\begin{array}{l}0.001 \\
(0.001)\end{array}$ & $-0.3 \%$ \\
\hline & Education & $\begin{array}{l}-0.029 \\
(0.001)^{* * *}\end{array}$ & $27.1 \%$ & $\begin{array}{l}-0.048 \\
(0.001)^{* * *}\end{array}$ & $31.0 \%$ & $\begin{array}{l}-0.091 \\
(0.002)^{* * *}\end{array}$ & $33.5 \%$ & $\begin{array}{l}-0.144 \\
(0.003)^{* * *}\end{array}$ & $38.5 \%$ & $\begin{array}{l}-0.142 \\
(0.003)^{* * *}\end{array}$ & $36.4 \%$ \\
\hline & Tenure & $\begin{array}{l}-0.019 \\
(0.001)^{* * *}\end{array}$ & $17.8 \%$ & $\begin{array}{l}-0.033 \\
(0.001)^{* * *}\end{array}$ & $21.3 \%$ & $\begin{array}{l}-0.056 \\
(0.002)^{* * *}\end{array}$ & $20.6 \%$ & $\begin{array}{l}-0.073 \\
(0.002)^{* * *}\end{array}$ & $19.5 \%$ & $\begin{array}{l}-0.068 \\
(0.003)^{* * *}\end{array}$ & $17.4 \%$ \\
\hline & Contract & $\begin{array}{l}-0.003 \\
(0.001)^{* * *}\end{array}$ & $2.8 \%$ & $\begin{array}{l}-0.001 \\
(0.001)^{* *}\end{array}$ & $0.6 \%$ & $\begin{array}{l}-0.003 \\
(0.001)^{* * *}\end{array}$ & $1.1 \%$ & $\begin{array}{l}-0.002 \\
(0.001)^{*}\end{array}$ & $0.5 \%$ & $\begin{array}{l}0.005 \\
(0.001)^{* * *}\end{array}$ & $-1.3 \%$ \\
\hline & Region & $\begin{array}{l}-0.001 \\
(0.001)^{* *}\end{array}$ & $0.9 \%$ & $\begin{array}{l}-0.001 \\
(0.001)^{* *}\end{array}$ & $0.6 \%$ & $\begin{array}{l}-0.004 \\
(0.001)^{* * *}\end{array}$ & $1.5 \%$ & $\begin{array}{l}-0.006 \\
(0.001)^{* * *}\end{array}$ & $1.6 \%$ & $\begin{array}{l}-0.013 \\
(0.001)^{* * *}\end{array}$ & $3.3 \%$ \\
\hline & Sector & $\begin{array}{l}-0.011 \\
(0.001)^{* * *}\end{array}$ & $10.3 \%$ & $\begin{array}{l}-0.020 \\
(0.001)^{* * *}\end{array}$ & $12.9 \%$ & $\begin{array}{l}-0.043 \\
(0.001)^{* * *}\end{array}$ & $15.8 \%$ & $\begin{array}{l}-0.063 \\
(0.002)^{* * *}\end{array}$ & $16.8 \%$ & $\begin{array}{l}-0.063 \\
(0.003)^{* * *}\end{array}$ & $16.2 \%$ \\
\hline & Size & $\begin{array}{l}-0.004 \\
(0.000)^{* * *}\end{array}$ & $3.7 \%$ & $\begin{array}{l}-0.005 \\
(0.001)^{* * *}\end{array}$ & $3.2 \%$ & $\begin{array}{l}-0.006 \\
(0.001)^{* * *}\end{array}$ & $2.2 \%$ & $\begin{array}{l}-0.006 \\
(0.001)^{* * *}\end{array}$ & $1.6 \%$ & $\begin{array}{l}-0.005 \\
(0.001)^{* * *}\end{array}$ & $1.3 \%$ \\
\hline & Collective agreement & $\begin{array}{l}0.001 \\
(0.001)\end{array}$ & $-0.9 \%$ & $\begin{array}{l}-0.004 \\
(0.001)^{* * *}\end{array}$ & $2.6 \%$ & $\begin{array}{l}-0.014 \\
(0.001)^{* * *}\end{array}$ & $5.1 \%$ & $\begin{array}{l}-0.019 \\
(0.001)^{* * *}\end{array}$ & $5.1 \%$ & $\begin{array}{l}-0.014 \\
(0.001)^{* * *}\end{array}$ & $3.6 \%$ \\
\hline$N$ & & 62,755 & & 62,755 & & 62,755 & & 62,755 & & 62,755 & \\
\hline
\end{tabular}

Notes: The right part of each column contains the contribution of each characteristic as a percentage of the total difference in hourly wages between part- and full-time workers.

$* p<0,1 ; * * p<0,05 ; * * * p<0,01$ 


\section{Appendix}

Table A.1. Descriptive statistics. Males.

\begin{tabular}{|c|c|c|c|c|c|c|c|c|c|c|c|c|}
\hline & \multicolumn{6}{|c|}{ Full-time } & \multicolumn{6}{|c|}{ Part-time } \\
\hline & \multicolumn{2}{|c|}{ Total } & \multirow{2}{*}{\multicolumn{4}{|c|}{$\begin{array}{c}\text { Average } \\
\text { Parts of the wage distribution }\end{array}$}} & \multicolumn{2}{|c|}{ Total } & \multirow{2}{*}{\multicolumn{4}{|c|}{$\begin{array}{c}\text { Average } \\
\text { Parts of the wage distribution }\end{array}$}} \\
\hline & Average & SD & & & & & Ayerage & SD & & & & \\
\hline & Average & S.D. & $<\mathrm{p} 25$ & p25-p50 & $\mathrm{p} 50-\mathrm{p} 75$ & $>\mathrm{p} 75$ & Average & S.D. & $<\mathrm{p} 25$ & $\mathrm{p} 25-\mathrm{p} 50$ & $\mathrm{p} 50-\mathrm{p} 75$ & $>\mathrm{p} 75$ \\
\hline Logarithm of hourly wage & 2.423 & 0.494 & 1.874 & 2.201 & 2.519 & 3.097 & 2.318 & 0.591 & 1.709 & 2.040 & 2.404 & 3.121 \\
\hline Immigrant & 0.065 & 0.247 & 0.124 & 0.072 & 0.037 & 0.028 & 0.093 & 0.297 & 0.147 & 0.128 & 0.060 & 0.036 \\
\hline Primary education & 0.183 & 0.387 & 0.278 & 0.232 & 0.157 & 0.067 & 0.233 & 0.423 & 0.259 & 0.224 & 0.251 & 0.198 \\
\hline Secondary education & 0.598 & 0.490 & 0.670 & 0.664 & 0.621 & 0.436 & 0.585 & 0.493 & 0.637 & 0.668 & 0.555 & 0.482 \\
\hline Tertiary education & 0.219 & 0.414 & 0.052 & 0.104 & 0.222 & 0.497 & 0.181 & 0.385 & 0.104 & 0.108 & 0.194 & 0.320 \\
\hline Age & 40.640 & 10.150 & 37.390 & 39.330 & 41.010 & 44.810 & 42.740 & 14.830 & 36.110 & 37.890 & 45.030 & 51.900 \\
\hline Tenure & 9.351 & 9.676 & 4.738 & 7.638 & 10.530 & 14.490 & 9.877 & 13.410 & 3.292 & 4.954 & 11.870 & 19.400 \\
\hline Fixed-term contract & 0.811 & 0.391 & 0.665 & 0.781 & 0.863 & 0.935 & 0.444 & 0.497 & 0.501 & 0.548 & 0.419 & 0.307 \\
\hline Andalusia & 0.099 & 0.299 & 0.103 & 0.104 & 0.090 & 0.101 & 0.111 & 0.314 & 0.134 & 0.121 & 0.095 & 0.095 \\
\hline Aragon & 0.042 & 0.201 & 0.035 & 0.051 & 0.050 & 0.034 & 0.038 & 0.191 & 0.028 & 0.037 & 0.044 & 0.042 \\
\hline Asturias & 0.034 & 0.181 & 0.034 & 0.037 & 0.038 & 0.026 & 0.028 & 0.164 & 0.025 & 0.021 & 0.026 & 0.038 \\
\hline Balearics & 0.023 & 0.151 & 0.030 & 0.028 & 0.020 & 0.016 & 0.052 & 0.223 & 0.044 & 0.052 & 0.062 & 0.051 \\
\hline Canary Islands & 0.042 & 0.201 & 0.073 & 0.037 & 0.030 & 0.029 & 0.033 & 0.179 & 0.061 & 0.027 & 0.026 & 0.019 \\
\hline Cantabria & 0.027 & 0.161 & 0.033 & 0.030 & 0.025 & 0.019 & 0.026 & 0.158 & 0.024 & 0.024 & 0.023 & 0.032 \\
\hline Castilla-Leon & 0.054 & 0.227 & 0.067 & 0.053 & 0.052 & 0.045 & 0.045 & 0.208 & 0.050 & 0.040 & 0.041 & 0.051 \\
\hline Castilla La Mancha & 0.042 & 0.201 & 0.055 & 0.047 & 0.037 & 0.029 & 0.032 & 0.176 & 0.029 & 0.036 & 0.037 & 0.026 \\
\hline Catalonia & 0.163 & 0.369 & 0.102 & 0.152 & 0.190 & 0.209 & 0.187 & 0.390 & 0.139 & 0.195 & 0.216 & 0.199 \\
\hline Valencia & 0.083 & 0.275 & 0.091 & 0.092 & 0.081 & 0.066 & 0.084 & 0.278 & 0.093 & 0.091 & 0.100 & 0.053 \\
\hline Extremadura & 0.024 & 0.151 & 0.050 & 0.020 & 0.013 & 0.012 & 0.017 & 0.127 & 0.030 & 0.019 & 0.011 & 0.007 \\
\hline Galicia & 0.055 & 0.228 & 0.081 & 0.065 & 0.043 & 0.031 & 0.040 & 0.196 & 0.042 & 0.045 & 0.034 & 0.040 \\
\hline Madrid & 0.171 & 0.377 & 0.138 & 0.138 & 0.169 & 0.240 & 0.172 & 0.377 & 0.209 & 0.181 & 0.142 & 0.157 \\
\hline Murcia & 0.031 & 0.174 & 0.046 & 0.036 & 0.024 & 0.020 & 0.026 & 0.159 & 0.038 & 0.027 & 0.025 & 0.014 \\
\hline Navarre & 0.030 & 0.169 & 0.015 & 0.033 & 0.044 & 0.027 & 0.029 & 0.166 & 0.009 & 0.026 & 0.032 & 0.047 \\
\hline Basque Country & 0.063 & 0.243 & 0.027 & 0.055 & 0.082 & 0.089 & 0.068 & 0.252 & 0.034 & 0.040 & 0.077 & 0.124 \\
\hline The Rioja & 0.016 & 0.125 & 0.022 & 0.021 & 0.014 & 0.007 & 0.012 & 0.109 & 0.012 & 0.020 & 0.010 & 0.007 \\
\hline Industry & 0.424 & 0.494 & 0.354 & 0.438 & 0.488 & 0.415 & 0.288 & 0.453 & 0.161 & 0.208 & 0.345 & 0.437 \\
\hline Construction & 0.122 & 0.327 & 0.171 & 0.154 & 0.096 & 0.066 & 0.037 & 0.188 & 0.027 & 0.047 & 0.042 & 0.031 \\
\hline Services & 0.454 & 0.498 & 0.475 & 0.408 & 0.416 & 0.518 & 0.675 & 0.468 & 0.812 & 0.745 & 0.613 & 0.532 \\
\hline Firm size less than 20 & 0.105 & 0.307 & 0.196 & 0.122 & 0.060 & 0.043 & 0.138 & 0.345 & 0.203 & 0.195 & 0.103 & 0.051 \\
\hline Firm size 10-49 & 0.238 & 0.426 & 0.332 & 0.287 & 0.198 & 0.137 & 0.195 & 0.396 & 0.236 & 0.228 & 0.182 & 0.134 \\
\hline Firm size 50-199 & 0.277 & 0.447 & 0.261 & 0.298 & 0.297 & 0.250 & 0.226 & 0.418 & 0.214 & 0.224 & 0.244 & 0.221 \\
\hline Firm size 500 or more & 0.380 & 0.485 & 0.211 & 0.293 & 0.445 & 0.571 & 0.441 & 0.497 & 0.348 & 0.353 & 0.471 & 0.594 \\
\hline National sect. collect. agr. & 0.286 & 0.452 & 0.319 & 0.282 & 0.255 & 0.288 & 0.282 & 0.450 & 0.380 & 0.312 & 0.238 & 0.200 \\
\hline Sub-national sect. coll. agr. & 0.416 & 0.493 & 0.527 & 0.507 & 0.385 & 0.243 & 0.388 & 0.487 & 0.362 & 0.466 & 0.424 & 0.302 \\
\hline Firm collective agreement & 0.299 & 0.458 & 0.154 & 0.211 & 0.360 & 0.469 & 0.329 & 0.470 & 0.258 & 0.222 & 0.338 & 0.498 \\
\hline Number of observations & & & 20,394 & 20,394 & 20,394 & 20,394 & & & 1,941 & 1,941 & 1,941 & 1,941 \\
\hline
\end{tabular}

variables for the four sections of the wage distribution defined by the three quartiles. 
Table A.2.

Descriptive statistics. Females.

\begin{tabular}{|c|c|c|c|c|c|c|c|c|c|c|c|c|}
\hline & \multicolumn{6}{|c|}{ Full-time } & \multicolumn{6}{|c|}{ Part-time } \\
\hline & \multicolumn{2}{|c|}{ Total } & \multirow{2}{*}{\multicolumn{4}{|c|}{$\begin{array}{c}\text { Average } \\
\text { Parts of the wage distribution }\end{array}$}} & \multicolumn{2}{|c|}{ Total } & \multirow{2}{*}{\multicolumn{4}{|c|}{$\begin{array}{c}\text { Average } \\
\text { Parts of the wage distribution }\end{array}$}} \\
\hline & Axerage & SD & & & & & & & & & & \\
\hline & Average & S.D. & $<\mathrm{p} 25$ & p25-p50 & $\mathrm{p} 50-\mathrm{p} 75$ & $>\mathrm{p} 75$ & Average & S.D. & $<\mathrm{p} 25$ & p25-p50 & $\mathrm{p} 50-\mathrm{p} 75$ & $>$ p75 \\
\hline Logarithm of hourly wage & 2.282 & 0.481 & 1.736 & 2.062 & 2.384 & 2.945 & 2.028 & 0.400 & 1.623 & 1.854 & 2.059 & 2.576 \\
\hline Immigrant & 0.102 & 0.303 & 0.191 & 0.129 & 0.064 & 0.024 & 0.200 & 0.400 & 0.261 & 0.240 & 0.199 & 0.101 \\
\hline Primary education & 0.051 & 0.222 & 0.093 & 0.057 & 0.034 & 0.024 & 0.080 & 0.271 & 0.097 & 0.087 & 0.069 & 0.068 \\
\hline Secondary education & 0.542 & 0.498 & 0.703 & 0.651 & 0.539 & 0.274 & 0.637 & 0.481 & 0.678 & 0.672 & 0.669 & 0.529 \\
\hline Tertiary education & 0.356 & 0.479 & 0.105 & 0.220 & 0.397 & 0.701 & 0.163 & 0.369 & 0.061 & 0.088 & 0.131 & 0.370 \\
\hline Age & 39.080 & 9.826 & 37.090 & 37.770 & 39.360 & 42.110 & 39.200 & 10.920 & 39.300 & 39.200 & 38.900 & 39.410 \\
\hline Tenure & 8.320 & 9.059 & 4.590 & 6.562 & 9.498 & 12.630 & 5.114 & 6.623 & 3.360 & 4.283 & 5.315 & 7.500 \\
\hline Fixed-term contract & 0.800 & 0.400 & 0.743 & 0.777 & 0.817 & 0.862 & 0.666 & 0.472 & 0.621 & 0.668 & 0.701 & 0.675 \\
\hline Andalusia & 0.080 & 0.272 & 0.077 & 0.087 & 0.080 & 0.078 & 0.134 & 0.341 & 0.166 & 0.138 & 0.119 & 0.113 \\
\hline Aragon & 0.038 & 0.191 & 0.038 & 0.047 & 0.041 & 0.025 & 0.036 & 0.186 & 0.027 & 0.037 & 0.043 & 0.037 \\
\hline Asturias & 0.025 & 0.156 & 0.043 & 0.028 & 0.017 & 0.013 & 0.025 & 0.155 & 0.038 & 0.030 & 0.014 & 0.016 \\
\hline Balearics & 0.026 & 0.158 & 0.025 & 0.023 & 0.027 & 0.027 & 0.037 & 0.189 & 0.029 & 0.027 & 0.043 & 0.050 \\
\hline Canary Islands & 0.044 & 0.205 & 0.059 & 0.045 & 0.037 & 0.035 & 0.040 & 0.196 & 0.068 & 0.035 & 0.029 & 0.027 \\
\hline Cantabria & 0.018 & 0.135 & 0.023 & 0.018 & 0.017 & 0.016 & 0.023 & 0.149 & 0.017 & 0.032 & 0.027 & 0.015 \\
\hline Castilla-Leon & 0.048 & 0.213 & 0.052 & 0.047 & 0.046 & 0.045 & 0.055 & 0.228 & 0.049 & 0.070 & 0.054 & 0.048 \\
\hline Castilla La Mancha & 0.037 & 0.188 & 0.044 & 0.039 & 0.032 & 0.032 & 0.029 & 0.167 & 0.034 & 0.032 & 0.026 & 0.024 \\
\hline Catalonia & 0.201 & 0.401 & 0.142 & 0.202 & 0.231 & 0.228 & 0.187 & 0.390 & 0.146 & 0.156 & 0.218 & 0.228 \\
\hline Valencia & 0.076 & 0.265 & 0.101 & 0.083 & 0.070 & 0.050 & 0.080 & 0.271 & 0.096 & 0.095 & 0.064 & 0.064 \\
\hline Extremadura & 0.016 & 0.125 & 0.023 & 0.011 & 0.014 & 0.015 & 0.020 & 0.139 & 0.036 & 0.015 & 0.016 & 0.012 \\
\hline Galicia & 0.059 & 0.236 & 0.094 & 0.061 & 0.048 & 0.035 & 0.047 & 0.211 & 0.070 & 0.052 & 0.036 & 0.029 \\
\hline Madrid & 0.223 & 0.416 & 0.182 & 0.192 & 0.226 & 0.291 & 0.170 & 0.376 & 0.138 & 0.187 & 0.164 & 0.189 \\
\hline Murcia & 0.026 & 0.158 & 0.033 & 0.024 & 0.024 & 0.021 & 0.027 & 0.163 & 0.037 & 0.027 & 0.025 & 0.020 \\
\hline Navarre & 0.020 & 0.141 & 0.017 & 0.027 & 0.026 & 0.011 & 0.020 & 0.139 & 0.008 & 0.016 & 0.029 & 0.026 \\
\hline Basque Country & 0.052 & 0.222 & 0.029 & 0.051 & 0.056 & 0.072 & 0.060 & 0.237 & 0.029 & 0.033 & 0.082 & 0.094 \\
\hline The Rioja & 0.012 & 0.108 & 0.018 & 0.017 & 0.008 & 0.005 & 0.013 & 0.111 & 0.012 & 0.018 & 0.011 & 0.009 \\
\hline Industry & 0.220 & 0.414 & 0.231 & 0.245 & 0.217 & 0.185 & 0.093 & 0.291 & 0.095 & 0.083 & 0.091 & 0.105 \\
\hline Construction & 0.014 & 0.117 & 0.007 & 0.016 & 0.017 & 0.015 & 0.005 & 0.073 & 0.003 & 0.005 & 0.007 & 0.006 \\
\hline Services & 0.766 & 0.423 & 0.762 & 0.739 & 0.765 & 0.800 & 0.902 & 0.298 & 0.903 & 0.912 & 0.902 & 0.889 \\
\hline Firm size less than 20 & 0.085 & 0.280 & 0.160 & 0.094 & 0.057 & 0.031 & 0.123 & 0.329 & 0.163 & 0.122 & 0.115 & 0.094 \\
\hline Firm size 10-49 & 0.171 & 0.377 & 0.249 & 0.202 & 0.144 & 0.091 & 0.153 & 0.360 & 0.153 & 0.153 & 0.162 & 0.142 \\
\hline Firm size 50-199 & 0.218 & 0.413 & 0.243 & 0.251 & 0.212 & 0.168 & 0.235 & 0.424 & 0.250 & 0.248 & 0.230 & 0.212 \\
\hline Firm size 500 or more & 0.525 & 0.499 & 0.349 & 0.453 & 0.587 & 0.711 & 0.489 & 0.500 & 0.434 & 0.477 & 0.493 & 0.552 \\
\hline National sect. collect. agr. & 0.349 & 0.477 & 0.421 & 0.353 & 0.316 & 0.307 & 0.304 & 0.460 & 0.331 & 0.299 & 0.292 & 0.294 \\
\hline Sub-national sect. coll. agr. & 0.303 & 0.460 & 0.388 & 0.370 & 0.269 & 0.186 & 0.458 & 0.498 & 0.433 & 0.530 & 0.490 & 0.380 \\
\hline Firm collective agreement & 0.348 & 0.476 & 0.192 & 0.277 & 0.415 & 0.507 & 0.238 & 0.426 & 0.236 & 0.172 & 0.217 & 0.327 \\
\hline Number of observations & \multicolumn{2}{|c|}{45,338} & 11,334 & 11,334 & 11,334 & 11,334 & \multicolumn{2}{|c|}{17,417} & 4,354 & 4,354 & 4,354 & 4,354 \\
\hline
\end{tabular}

Notes: The table includes descriptive (mean and standard deviation) for each of the groups (individuals with full- and part-time) and the value of the average of the variables for the four sections of the wage distribution defined by the three quartiles. 